\title{
Requirements for Pyocyanine Production by Pseudomonas aeruginosa (Schroeter) Migula
}

\author{
BY ESTHER HELLINGER
}

Daniel Sieff Research Institute, Rehovot, Israel

SUMMARY: Substances found to be essential for pyocyanine production by Pseudomonas aeruginosa were $\mathrm{Mg}, \mathrm{PO}_{4}, \mathrm{SO}_{4}$ and $\mathrm{NH}_{4}$ ions, together with a carbon source, preferably glucose, glycerol or ethanol. $\mathrm{Ca}, \mathrm{Na}, \mathrm{K}, \mathrm{Fe}$ ions were not essential, nor was asparagine. Pyocyanine was formed in nutrient broth prepared with distilled water; the addition of chalk improved pigment production. Reliable and good yields were regularly obtained on an ordinary broth medium containing glucose $(0 \cdot 2 \%)$ and chalk.

Recommended media for stimulating pyocyanine production were tested. Turfitt's medium gave more reliable pyocyanine formation when the $\mathrm{NH}_{4} \mathrm{NO}_{3}$ was replaced by $\mathrm{NH}_{4} \mathrm{Cl}$ and chalk was added. Increasing the $\mathrm{MgSO}_{4} \cdot 7 \mathrm{H}_{2} \mathrm{O}$ content of this medium from $0.025 \%$ to $0.2 \%$ inhibited pyocyanine production.

Various amino-acids were tested. Glycine, r-tyrosine, DL-alanine, L-leucine, when added separately or in various combinations to a salt mixture+glucose, glycerol or ethanol permitted the production of pyocyanine. A mixture of glycine, L-leucine and DL-alanine (recommended by Burton, Campbell \& Eagles, 1947) exerted a stimulating effect on pyocyanine production far superior to that obtained on any other medium tested.

The highest yield reached was $23 \cdot 1 \mathrm{mg}$. pyocyanine $/ 100 \mathrm{ml}$. of a medium consisting of: $0.4 \%$ DL-alanine; $0.8 \%$ L-leucine; $0.2 \% \quad \mathrm{MgSO}_{4} \cdot \mathbf{7 H}_{2} \mathrm{O} ; \mathbf{0 . 0 5} \% \mathbf{K}_{2} \mathrm{HPO}_{4}$; $0.001 \% \mathrm{FeSO}_{4} \cdot 7 \mathrm{H}_{2} \mathrm{O} ; 1 \%$ glycerol and chalk.

There is agreement in the literature that sulphate, phosphate and magnesium are essential for pyocyanine production by Pseudomonas aeruginosa (Ps. pyocyanea). Jamieson (1942) reported that, by chance using tap water of lake origin for his media, the majority of certain organisms he had previously considered to be Achromobacter spp. produced blue-green pigment; this would place them as Pseudomonas spp. Even media such as proteose-peptone when prepared with distilled water, failed to yield pigment, but with tap water did so. Jamieson found that best pigmentation was produced on Sullivan's medium: asparagine $1 \%$, magnesium sulphate $0.2 \%$; dipotassium phosphate $0.1 \%$; distilled water. He thought this was due primarily to asparagine being a source of nitrogen more adequate for pigment formation than peptone. Burton, Campbell \& Eagles (1948) found that $\mathrm{K}$ and $\mathrm{Fe}$ ions in addition to $\mathrm{SO}_{4}, \mathrm{PO}_{4}$, and $\mathrm{Mg}$ ions were necessary. They stated that $\mathrm{Na}, \mathrm{NH}_{4}, \mathrm{Mn}, \mathrm{Zn}$, $\mathrm{AsO}_{4}$ or $\mathrm{Cu}$ could not be substituted in their defined medium (containing also $1 \%$ glycerol, $0.6 \%$ glycine, $0.6 \%$ leucine) for the above ions, and that $\mathbf{N H}_{4}$, $\mathrm{Mn}, \mathrm{Zn}, \mathrm{AsO}_{4}$ and $\mathrm{Cu}$ ions inhibited pyocyanine production. On the other hand Liot (1923) found that ammonium ion (as an organic salt) was necessary for pyocyanine formation. Young (1947) found that no pigment was produced in media containing over $1 \%$ glucose, the inhibition being attributed to the attainment of low $\mathrm{pH}$ values. Turfitt (1937) recommended the 
following medium for good pigmentation: $\mathrm{NH}_{4} \mathrm{NO}_{3}, 0.1 \% ; \mathrm{K}_{2} \mathrm{HPO}_{4}, 0.025 \%$; $\mathrm{MgSO}_{4} \cdot 7 \mathrm{H}_{2} \mathrm{O}, 0.025 \%$; ethanol, $0 \cdot 1 \%$; distilled water.

A strain of Ps. aeruginosa isolated by the author from the River Yarkon, Israel, showed no pigment production under anaerobic conditions, but produced good pigmentation when grown aerobically on nutrient broth or nutrient agar prepared with distilled water. Because of this difference from Jamieson's findings, the requirements of our strain of Ps. aeruginosa for pyocyanine production were examined.

\section{METHODS AND MEDIA}

Method of estimating pyocyanine. The pyocyanine was extracted from culture media and the colour intensity of extracts was compared with those of known concentrations of pure pyocyanine in chloroform with a photoelectric colorimeter (Lumetron Electrophotometer; scale standardized at 100 with pure chloroform, colour filter 620, light intensity +10 ). The logarithms of the Lumetron readings when plotted against pyocyanine concentration gave a straight line relationship.

Growth and extraction of pyocyanine. Twenty ml. quantities of medium in $50 \mathrm{ml}$. round, flat-bottom flasks were sterilized at $110^{\circ}$ for $45 \mathrm{~min}$. The $\mathrm{pH}$ after sterilizing was determined on separate $5 \mathrm{ml}$. quantities. Each flask was inoculated with one loopful of a young active culture and incubated at $37^{\circ}$. In the first experiments, one set of flasks was examined for pyocyanine on the 7th or 8th day, and a further set after a longer incubation period. In later experiments pyocyanine extractions were carried out on the 4th and 7th/8th day. In practically all cases pigment production decreased on prolonging the incubation beyond 4-5 days.

Table 1. The composition of various media used to ascertain requirements of Ps. aeruginosa for pyocyanine production

\begin{tabular}{|c|c|c|c|c|c|c|c|c|c|c|c|c|c|c|c|}
\hline \multirow[b]{2}{*}{ Constituent } & & \multicolumn{14}{|c|}{ Medium number } \\
\hline & $\begin{array}{l}\text { centration } \\
(\%)\end{array}$ & 1 & 2 & 3 & 4 & 5 & 6 & 7 & 8 & 9 & 10 & 11 & 12 & 16 & 17 \\
\hline $\mathrm{MgSO}_{4} \cdot 7 \mathrm{H}_{2} \mathrm{O}$ & 0.02 & - & + & + & + & - & + & + & + & + & + & - & + & - & + \\
\hline $\mathrm{CaCl}_{2}$ & 0.01 & + & - & + & + & + & + & + & + & + & + & - & - & - & - \\
\hline $\mathrm{NaCl}$ & $0 \cdot 1$ & + & + & - & + & + & + & + & + & + & + & - & - & - & - \\
\hline $\mathrm{KH}_{2} \mathrm{PO}_{4}$ & $0 \cdot 1$ & + & + & + & - & + & + & + & - & + & + & + & + & - & - \\
\hline $\mathrm{K}_{2} \mathrm{HPO}_{4}$ & $0 \cdot 1$ & - & - & - & - & - & - & - & - & - & - & + & + & + & + \\
\hline $\mathrm{MgCl}_{2}$ & $0 \cdot 02$ & - & - & - & - & + & - & - & - & - & - & - & - & - & - \\
\hline $\mathrm{Na}_{3} \mathrm{PO}_{4}$ & 0.2 & - & - & - & - & - & - & - & + & - & - & - & - & - & - \\
\hline $\mathrm{NaHCO}_{3}$ & $0 \cdot 1$ & - & - & - & + & - & - & - & - & - & - & - & - & - & - \\
\hline $\mathrm{FeCl}_{3}$ & 0.001 & - & + & + & + & + & + & - & + & + & + & - & - & - & - \\
\hline $\mathrm{FeSO}_{4} \cdot 7 \mathrm{H}_{2} \mathrm{O}$ & 0.001 & + & - & - & - & - & - & - & - & - & - & - & - & - & - \\
\hline $\mathrm{KNO}_{3}$ & $0 \cdot 1$ & - & - & - & + & - & + & - & - & - & - & - & - & - & - \\
\hline $\mathrm{NH}_{4} \mathrm{NO}_{3}$ & $0 \cdot 1$ & + & + & + & + & + & - & + & + & + & + & - & - & - & + \\
\hline Glycerol & $2 \cdot 0$ & + & + & + & + & + & + & + & + & - & + & + & + & + & + \\
\hline Asparagine & 0.05 & + & + & + & + & + & + & + & + & + & - & + & + & + & + \\
\hline
\end{tabular}


The individual cultures were extracted with 4-5 successive portions (5 ml.) of chloroform. Generally the chloroform extract was turbid; it was easily cleared by a brief centrifugation. To ensure perfect clarity for colorimetric measurements it was filtered through a filter paper wetted with chloroform, and the volume made up the original volume of the culture. When too concentrated the solution was suitably diluted.

Media. The composition of fourteen media is given in Table 1. In addition the two media recommended by Turfitt (1937) for stimulating the green fluorescent pigment of Ps. fluorescens $\left(0.05 \% \mathrm{MgSO}_{4} \cdot 7 \mathrm{H}_{2} \mathrm{O} ; 0.05 \% \mathrm{~K}_{2} \mathrm{HPO}_{4}\right.$; $0.3 \%$ asparagine) and pyocyanine production by $P$ s. pyocyanea $(0.025 \%$ $\mathrm{MgSO}_{4} .7 \mathrm{H}_{2} \mathrm{O} ; 0.025 \% \mathrm{~K}_{2} \mathrm{HPO}_{4} ; 0.1 \% \mathrm{NH}_{4} \mathrm{NO}_{3} ; 0.1 \%$ ethanol) were tested (media 18 and 19 respectively). Other media tested were: standard broth containing $0.3 \%$ Difco meat extract $+0.5 \%$ Bacto Proteose peptone made up with distilled water (No. 13); the same $+0.2 \%$ glucose (No. 14); standard broth $+\mathbf{0 . 2} \%$ glucose + chalk (No. 15).

\section{RESULTS}

In the first series of experiments (Table 2) growth occurred in all media except that containing no phosphate (No. 4). The defined media Nos. 1 to 10, when lacking $\mathrm{Mg}, \mathrm{SO}_{4}, \mathrm{PO}_{4}, \mathrm{NH}_{4}$ or glycerol, failed to produce pyocyanine. $\mathrm{Ca}$,

Table 2. Effect of composition of medium on groroth, $p H$ and pyocyanine production by Ps. aeruginosa grown at $37^{\circ}$

\begin{tabular}{|c|c|c|c|c|c|c|c|}
\hline \multirow{3}{*}{$\begin{array}{l}\text { Medium } \\
\text { No. }\end{array}$} & \multirow[b]{3}{*}{ Growth } & \multicolumn{4}{|c|}{$\mathrm{pH}$ values } & & \\
\hline & & \multicolumn{2}{|c|}{$\begin{array}{l}\text { Initial } \\
\text { Series }\end{array}$} & \multicolumn{2}{|c|}{$\begin{array}{l}\text { Final } \\
\text { Series }\end{array}$} & \multicolumn{2}{|c|}{$\begin{array}{c}\text { Pyocyanine } \\
\text { mg./100 ml. medium }\end{array}$} \\
\hline & & 1 & 2 & 1 & 2 & 1* & 2*** \\
\hline 1 & moderate & $6 \cdot 4$ & $6 \cdot 4$ & $7 \cdot 3$ & $8 \cdot 1$ & None & None \\
\hline 2 & good & $6 \cdot 3$ & $6 \cdot 4$ & 6.1 & $6 \cdot 4$ & $2 \cdot 45$ & 0.85 \\
\hline $\mathbf{3}$ & good & $6 \cdot 4$ & $6 \cdot 4$ & 6.2 & $6 \cdot 3$ & $2 \cdot 24$ & 0.28 \\
\hline 4 & none & 6.7 & $6 \cdot 4$ & 6.7 & $7 \cdot 6$ & None & None \\
\hline 5 & good & $6 \cdot 3$ & $6 \cdot 3$ & $7 \cdot 5$ & $7 \cdot 0$ & Traces & None \\
\hline 6 & good & $6 \cdot 4$ & 6.5 & $6 \cdot 8$ & $7 \cdot 5$ & None & None \\
\hline 7 & good & $6 \cdot 3$ & $6 \cdot 4$ & $6 \cdot 3$ & $6 \cdot 2$ & 1.87 & $0 \cdot 1$ \\
\hline 8 & good & $7 \cdot 8$ & 6.9 & $7 \cdot 4$ & $6 \cdot 8$ & 1.79 & $0 \cdot 1$ \\
\hline 9 & good & $6 \cdot 3$ & $6 \cdot 9$ & 6.5 & $7 \cdot 3$ & None & None \\
\hline 10 & good & $6 \cdot 3$ & $6 \cdot 4$ & $6 \cdot 1$ & $5 \cdot 7$ & 1.72 & $0 \cdot 15$ \\
\hline 11 & moderate & $6 \cdot 6$ & - & $6 \cdot 5$ & - & None & . \\
\hline 12 & moderate & $6 \cdot 5$ & - & 4.9 & - & None & . \\
\hline 13 & very good & 6.5 & $6 \cdot 9$ & $8 \cdot 8$ & $8 \cdot 7$ & 0.4 & $0 \cdot 18$ \\
\hline & & & & & 8.7 & & $1 \cdot 37+$ \\
\hline 14 & very good & $6 \cdot 4$ & $6 \cdot 7$ & $7 \cdot 3$ & $7 \cdot 4$ & $1 \cdot 62$ & 0.29 \\
\hline 15 & very good & $7 \cdot 4$ & $7 \cdot 4$ & $8 \cdot 6$ & $8 \cdot 7$ & $5 \cdot 62$ & $12 \cdot 63$ \\
\hline & & & & & $8 \cdot 7$ & & $9.38+$ \\
\hline 16 & fair & $7 \cdot 7$ & - & 6.5 & - & None & . \\
\hline 17 & good & $7 \cdot 5$ & - & $4 \cdot 9$ & - & 0.15 & . \\
\hline 18 & good & $7 \cdot 7$ & $7 \cdot 0$ & $7 \cdot 8$ & $8 \cdot 5$ & None & None \\
\hline 19 & good & $7 \cdot 8$ & 7.0 & $7 \cdot 2$ & $4 \cdot 2$ & $1 \cdot 42$ & None \\
\hline
\end{tabular}

*=Series 1 tested on 7th day; **=Series 2 tested on 8th day; $+=$ chalk added to medium. 
$\mathrm{Na}, \mathrm{K}, \mathrm{Fe}$ ions and asparagine were not essential for pigment formation. Substitution of $\mathrm{KNO}_{3}$ for $\mathrm{NH}_{4} \mathrm{NO}_{3}$ (No. 6) did not stimulate pyocyanine formation, indicating that the ammonium ion was required and not nitrate ion. In medium No. 12 (a defined medium containing $\mathrm{Mg}, \mathrm{SO}_{4}, \mathrm{PO}_{4}$, asparagine and glycerol, but no $\mathrm{NH}_{4}$ ion) pigment was produced, confirming the need for ammonium nitrogen. Turfitt's medium for Ps. fluorescens lacking in glycerol and ammonium salts but containing the essential ions $\mathrm{Mg}, \mathrm{SO}_{4}, \mathrm{PO}_{4}$, with asparagine as nitrogen source (No. 18), also did not yield pyocyanine. In Turfitt's medium for Ps. aeruginosa containing $\mathrm{Mg}, \mathrm{SO}_{4}, \mathrm{PO}_{4}$, and $\mathrm{NH}_{4}$ ions, and ethanol instead of glycerol (No. 19), pyocyanine was formed but only after four days. Medium No. 17 which contained the substances which appeared to be essential for pigment formation $\left(\mathrm{Mg}, \mathrm{SO}_{4}, \mathrm{PO}_{4}, \mathrm{NH}_{4}\right.$ ions and glycerol) gave at first a faint greenish pigmentation, which turned pink and became reddish by the fourth day, presumably due to the low $\mathrm{pH}$ reached; the acid salt of pyocyanine is port-wine coloured. On making alkaline a little pyocyanine was extractable from these cultures.

The best production of pyocyanine occurred on standard broth containing glucose $(0 \cdot 2 \%)+$ chalk (Medium 15): yields as high as $12 \cdot 6 \mathrm{mg}$. pyocyanine/100 ml. medium were obtained. On unsupplemented standard broth pigmentation was erratic; some pyocyanine was formed when $0.2 \%$ glucose (without chalk) was added.

Ammonia, which appeared to be essential for pigment formation, is liberated by the organism from the peptone in standard broth. Turfitt's relatively simple medium (No. 19) contains $\mathrm{NH}_{4} \mathrm{NO}_{3}$, but this medium was unreliable for pyocyanine production; fluorescin, which is also produced, was at times the sole pigment present. Trials were made substituting $\mathrm{NH}_{4} \mathrm{Cl}$ for the $\mathrm{NH}_{4} \mathrm{NO}_{3}$ in this medium and doubling the ethanol content (i.e. to $0.2 \%$ ); the $\mathrm{pH}$ of all media was adjusted to $7 \cdot 4$. In one medium of this series, ethanol was replaced by glycerol, and asparagine used instead of ammonium salt; growth was good, the $\mathrm{pH}$ of the medium rose to 8 , fluorescin but no pyocyanine was formed. Pyocyanine formation was erratic on Turfitt's medium both with and without chalk. With $\mathrm{NH}_{4} \mathrm{Cl}$ growth was fair to moderate, the $\mathrm{pH}$ of the culture medium always fell to $4 \cdot 4-5 \cdot 2$, but no pyocyanine was formed; with the addition of chalk, the $\mathrm{pH}$ rose to $8 \cdot 1$ and pyocyanine was regularly formed although in variable amounts, the highest being $3 \cdot 3 \mathrm{mg} . / 100 \mathrm{ml}$. medium. In general $\mathrm{NH}_{4} \mathrm{Cl}$ with chalk was more reliable for pyocyanine formation and gave higher yields than $\mathrm{NH}_{4} \mathrm{NO}_{3}$. These chemically defined media were not as good for pyocyanine production as standard broth containing glucose and chalk.

L-Tyrosine, L-tryptophan, L-cystine and glycine were added separately and in various combinations to $\mathbf{0 . 2} \%$ glucose, $2 \%$ glycerol or $0.2 \%$ ethanol; the salts present were: $0.025 \% \mathrm{MgSO}_{4} .7 \mathrm{H}_{2} \mathrm{O} ; 0.025 \% \mathrm{~K}_{2} \mathrm{HPO}_{4} ; 1 \% \mathrm{NH}_{4} \mathrm{NO}_{3}$ or $\mathrm{NH}_{4} \mathrm{Cl}$. The media were adjusted to $\mathrm{pH} \mathbf{7 \cdot 4}$ and cultures incubated for four days at $37^{\circ}$. All cultures showed good growth, the final $\mathrm{pH}$ varying from $7 \cdot 6$ to $8 \cdot 7$. Pyocyanine was produced only in the media containing tyrosine or glycine. Yields from glycine media were distinctly better than from tyrosine 
media; the presence of chalk increased these yields, although the effect was apparently not due to control of $\mathrm{pH}$. There were no striking differences between media containing either glucose, ethanol or glycerol. A comparison of pyocyanine yields from media containing $0.2 \%$ glycine+ammonium salts, with those from media lacking glycine, gave results somewhat in favour of the latter.

The two media of Burton, Eagles \& Campbell (1947) and recommended by them for maximum production of pyocyanine were compared with the standard broth containing glucose and chalk. One of these media contained

Table 3. Effect on pyocyanine production of L-leucine, with glycine or DL-alanine in a glycerol+salt mixture,* as compared with standard broth +glucose

\begin{tabular}{|c|c|c|c|c|c|c|}
\hline & \multicolumn{2}{|c|}{$\begin{array}{l}0.4 \% \text { glycine }+ \\
0.8 \% \text { L-leucine }\end{array}$} & \multicolumn{2}{|c|}{$\begin{array}{c}0.4 \% \text { DL-alanine }+ \\
0.8 \% \text { L-leucine }\end{array}$} & \multicolumn{2}{|c|}{$\begin{array}{c}\text { Standard broth }+ \\
0.2 \% \text { glucose }\end{array}$} \\
\hline & $-\mathrm{CaCO}_{3}$ & $+\mathrm{CaCO}_{3}$ & $-\mathrm{CaCO}_{3}$ & $+\mathrm{CaCO}_{3}$ & $-\mathrm{CaCO}_{3}$ & $+\mathrm{CaCO}_{3}$ \\
\hline $\begin{array}{l}\text { Final pH } \\
\text { Pyocyanine (mg./ }\end{array}$ & $\mathbf{8 \cdot 0}$ & $7 \cdot 7$ & $8 \cdot 1$ & $7 \cdot 9$ & $8 \cdot 6$ & $8 \cdot 7$ \\
\hline $100 \mathrm{ml}$. medium) & $14 \cdot 5$ & $19 \cdot 5$ & $19 \cdot 5$ & $23 \cdot 1$ & $7 \cdot 3$ & $9 \cdot 15$ \\
\hline
\end{tabular}

$0.4 \%$ glycine, the second $0.4 \%$ DL-alanine; both were at $\mathrm{pH} \mathbf{7 \cdot 4}$ and contained also $0.8 \%$ L-leucine, $1 \%$ glycerol and a salt mixture $\left(\mathrm{MgSO}_{4} \cdot \mathbf{7} \mathrm{H}_{2} \mathrm{O}\right.$, $0.2 \% ; \mathrm{K}_{2} \mathrm{HPO}_{4}, 0.04 \% ; \mathrm{FeSO}_{4} .7 \mathrm{H}_{2} \mathrm{O}, 0.001 \%$ ). Pyocyanine extractions were carried out after four days at $37^{\circ}$. The results (Table 3) with both media of Burton et al. were striking; they gave yields of pyocyanine far superior to the supplemented standard broth. The addition of chalk to the media of Burton et al. tended further to increase the pyocyanine yield.

Table 4. Pyocyanine production on various media

(The growth was very good in all media.)

\begin{tabular}{|c|c|c|c|c|c|}
\hline No. & Medium & & $\mathrm{CaCO}_{3}$ & $\begin{array}{c}\text { Final } \\
\text { pH value }\end{array}$ & $\begin{array}{c}\text { Pyocyanine } \\
\text { (mg./100 ml. medium) }\end{array}$ \\
\hline 1 & $\begin{array}{l}\mathrm{MgSO}_{4} \cdot 7 \mathrm{H}_{2} \mathrm{O} \\
\mathrm{K}_{2} \mathrm{HPO}_{4} \\
\mathrm{NH}_{4} \mathrm{Cl} \\
\text { Ethanol }\end{array}$ & $\left.\begin{array}{l}0.2 \% \\
0.04 \% \\
0.1 \% \\
0.2 \%\end{array}\right\}$ & - & $4 \cdot 6$ & (trace) \\
\hline 2 & $\begin{array}{l}\mathrm{MgSO}_{4} \cdot 7 \mathrm{H}_{2} \mathrm{O} \\
\mathrm{K}_{2} \mathrm{HPO}_{4} \\
\text { Glycine } \\
\text { L-Leucine } \\
\text { Ethanol }\end{array}$ & $\left.\begin{array}{l}0.2 \% \\
0.04 \% \\
0.4 \% \\
0.8 \% \\
0.2 \%\end{array}\right\}$ & - & $8 \cdot 3$ & $6 \cdot 85$ \\
\hline $\mathbf{3}$ & $\begin{array}{l}\text { As No. } 2+ \\
\mathrm{FeSO}_{4} \cdot 7 \mathrm{H}_{2} \mathrm{O}\end{array}$ & $(0.001 \%)$ & $\bar{t}$ & $\begin{array}{l}8 \cdot 6 \\
8 \cdot 4\end{array}$ & $\begin{array}{l}5 \cdot 46 \\
5 \cdot 73\end{array}$ \\
\hline 4 & $\begin{array}{l}\text { As No. } 3 \text { but w } \\
\text { glycerol ( } 1 \%) \\
\text { placing ethanol }\end{array}$ & 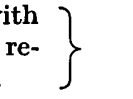 & $\begin{array}{l}- \\
+\end{array}$ & $\begin{array}{l}6.9 \\
6.9\end{array}$ & $\begin{array}{l}10 \cdot 44 \\
10 \cdot 44\end{array}$ \\
\hline 5 & $\begin{array}{l}\text { Standard broth } \\
\text { glucose (0.2\%) }\end{array}$ & & $\bar{t}$ & $\begin{array}{l}8 \cdot 6 \\
8 \cdot 4\end{array}$ & $\begin{array}{l}3 \cdot 58 \\
7 \cdot 19\end{array}$ \\
\hline
\end{tabular}


In further tests with the media of Burton et al. it was found (Table 4) (a) that although comparatively good yields of pyocyanine were obtained with ethanol, glycerol was better; (b) ferrous sulphate did not appear to exert an influence on pyocyanine formation; $(c)$ increasing the concentration of $\mathrm{MgSO}_{4} \cdot \mathbf{7} \mathrm{H}_{2} \mathrm{O}$ from $0.025 \%$ to $0.2 \%$ inhibited pyocyanine formation in the given medium.

\section{DISCUSSION}

The results obtained with our strain of $P s$. aeruginosa do not agree with Jamieson's (1942) finding that tap water was essential for pyocyanine formation on nutrient broth; pyocyanine was obtained in nutrient broth cultures prepared with distilled water, but the addition of calcium carbonate did enhance its formation. Wrede \& Strack (1924) found that media containing asparagine +glucose as carbon source gave good pyocyanine yields, and recognized the importance of maintaining the organism in a medium containing peptone $(1 \%)$ to preserve its ability to give good yields of pigment. In the present experiments asparagine was not essential for pyocyanine formation; when it was added to a medium containing glycerol, $\mathrm{MgSO}_{4}$ and $\mathrm{K}_{2} \mathrm{HPO}_{4}$ no pyocyanine was formed, yet on replacing asparagine with an ammonium salt pyocyanine was formed. Peptone is favourable for the maintenance of the organism's ability to give good yields, but a peptone medium did not ensure high pyocyanine yields unless the medium also contained glucose and chalk. We obtained pyocyanine in nutrient media $+2 \%$ glucose, whereas Young (1947) found no pigment in media containing over $1 \%$ glucose.

The present findings do not agree with those of Burton et al. (1948) that $\mathrm{K}$ and $\mathrm{Fe}$ are essential ions for pyocyanine formation. The media used without added iron contained less than 0.02 p.p.m. iron and yet pyocyanine was formed.

Ammonium ion appeared essential for pigment formation and we do not agree with Liot (1923) who claimed that pyocyanine is formed only in the presence of an organic ammonium salt. Ammonium salts as sole nitrogen source in media containing $0.025 \% \mathrm{MgSO}_{4} \cdot 7 \mathrm{H}_{2} \mathrm{O}, 0.025 \% \mathrm{~K}_{2} \mathrm{HPO}_{4}$, with glucose, glycerol or ethanol gave somewhat better yields than when glycine was added to the medium, whereas in media containing $0.2 \% \mathrm{MgSO}_{4} \cdot 7 \mathrm{H}_{2} \mathrm{O}$ and $0.04 \% \mathrm{~K}_{2} \mathrm{HPO}_{4}$ pyocyanine production was inhibited. Turfitt's medium for pyocyanine formation was found to be unreliable, but by replacing ammonium nitrate with ammonium chloride and chalk the pigment was regularly formed.

The media devised by Burton et al. (1948) were superior in supporting pyocyanine production to all the other media tested with a particular strain of $P s$. aeruginosa in the present work.

I wish to express my gratitude to my laboratory assistant Mr Haim Gruener for his valuable help. I also thank my colleague Dr Frieda Goldschmidt for kindly testing the media for contaminating iron. 


\section{REFERENCES}

Burton, M. O., Eagles, B. A. \& Campbell, J. J. R: (1947). The amino-acid requirements for pyocyanine production. Canad. J. Res., C. 25, 121.

Burton, M. O., Campbelx, J. J. R. \& Eagles, B. A. (1948). The mineral requirements for pyocyanine production. Canad. J. Res., C. 26, 15.

JAMIESON, M. C. (1942). Requisites for recognition of the blue-green Pseudomonas. Sci. Agric. 22, 401.

Liot, A. (1923). Culture du bacille pyocyanique sur milieux chimiquement définis. Ann. Inst. Pasteur, 37, 234.

TURFITT, G. E. (1937). Bacteriological and biochemical relationships in the pyocyaneus-fluorescens group. II. Investigations on the green fluorescent pigment. Biochem. J. 31, 212.

Wrede, F. \& Strack, E. (1924). Über das Pyocyanin, den blauen Farbstoff des Bacillus Pyocyaneus. I. Hoppe-Seyl. Z. 140, 1.

Young, C. (1947). Pigment production and antibiotic activity in cultures of Pseudomonas aeruginosa. J. Bact. 54, 109.

(Received 18 July 1950) 